\title{
Isolation of colonial variants of Bacteroides gingivalis W50 with a reduced virulence
}

\author{
AILSA S. MCKEE, ANN S. MCDERMID, R. WAIT, A. BASKERVILLE and P. D. MARSH* \\ Pathology Division, PHLS Centre for Applied Microbiology and Research, Porton Down, Salisbury, Wiltshire \\ SP4 OJG
}

\begin{abstract}
Summary. The spontaneous appearance of unusual colony forms was observed during prolonged growth of Bacteroides gingivalis W50 in a chemostat. Two variants were selected for further study which could be distinguished from the parent strain by the rate and intensity of pigmentation of their colonies. For example, after anaerobic incubation for 14 days, variant W50/BR1 produced brown colonies whereas those of the parent strain were black; in contrast, variant W50/BE1 did not show signs of pigmentation until incubation had continued for 21 days. In subsequent studies in the chemostat, variant W50/BE1 bred true even after prolonged growth whereas other colony forms appeared after incubation of variant W50/BR1 for 14 days. The relatedness of $\mathrm{W} 50 / \mathrm{BR} 1$ and $\mathrm{W} 50 / \mathrm{BE} 1$ to the parent strain was confirmed by comparisons of the whole-cell fatty-acid profiles, the patterns of pre-formed enzymes and by the metabolic end products after growth. However, the variants did differ from the parent strain in their virulence in a mouse pathogenicity model. The parent strain killed all mice given infective doses $>5 \times 10^{8}$ cfu whereas W50/BR1 was much less virulent ( 2 out of 10 mice killed and higher infective doses needed for higher mortality rates) and W50/BE1 was avirulent at all infective doses tested.
\end{abstract}

\section{Introduction}

Bacteroides gingivalis, a member of the blackpigmented group of Bacteroides, has been implicated as a major pathogen in the aetiology of some human periodontal diseases, particularly chronic inflammatory periodontal disease in adults (Slots, 1982a). Representative strains of this species have also been shown to be highly virulent in experimental animal infections (van Steenbergen et al., 1982), although recently this virulence has been shown to depend on the haemin concentration of the growth environment (McKee et al., 1986). B. gingivalis produces a wide range of factors that might contribute to its pathogenicity. These include the abilities to (i) damage host tissues directly through the production of enzymes and cytotoxic metabolites, (ii) damage host tissues indirectly by inducing an inflammatory response, and (iii) evade certain host defences by capsule formation and protease production (Slots and Genco, 1984). To determine the relative significance of individual factors, mutants defective in specific traits would be of

Received 19 Jan. 1988; accepted 11 Feb. 1988.

* Correspondence should be sent to Dr P. D. Marsh. particular value. During the prolonged growth of $B$. gingivalis W50 in a chemostat, unusual colony forms were observed in low numbers when small volumes of the culture were plated on to blood-agar plates. These colonies produced pigment only weakly, but the detection of key chemotaxonomic markers established their relatedness to the parent strain. The colonial variants were then compared in an animal pathogenicity test.

\section{Materials and methods}

\section{Bacterial strains}

The bacteria used in this study were $B$. gingivalis W50, $B$. asaccharolyticus B536 and $B$. intermedius T588 (kindly provided by $\mathrm{Dr} \mathrm{H}$. Shah, The London Hospital Medical College, London), B. endodontalis HG370 (kindly provided by Dr T. J. M. van Steenbergen, Vrije Universiteit, Amsterdam), and $B$. fragilis NCTC 9344 . The bacteria were maintained on blood agar and stored by lyophilisation.

\section{Growth of B. gingivalis in the chemostat}

$B$. gingivalis W50 was grown in an LH series II modular chemostat (LH Engineering, Stoke Poges) as described 
previously (McKee et al., 1986). Briefly, cells were grown at a constant $\mathrm{pH}$ of $7 \cdot 5 \pm 0.2$ and a dilution rate of $0.1 \mathrm{~h}^{-1}$ (this corresponds to a constant mean generation time of 6.9h). The temperature for growth was $36^{\circ} \mathrm{C}$ and the culture was gassed continuously with $\mathrm{CO}_{2} 5 \%, \mathrm{~N}_{2} 95 \%$. A modified complex medium (BM), supplemented with haemin $2.5 \mathrm{mg} / \mathrm{L}$ but no vitamin $\mathrm{K}_{1}$ was used as before to give conditions of haemin excess. The chemostat was inoculated and monitored regularly for $\mathrm{pH}, \mathrm{Eh}$, turbidity and dry weight of bacteria as described previously (McKee et al., 1986).

\section{Viable counts and recognition of colonial variants}

Viable counts were determined at frequent intervals to assess the purity and yield of the chemostat cultures. Culture fluid was serially diluted in BM broth and $100 \mu \mathrm{l}$ of each dilution was plated on to $10 \% \mathrm{v} / \mathrm{v}$ horse-bloodagar plates (Blood Agar Base no 2, Oxoid). Plates were incubated at $37^{\circ} \mathrm{C}$ for up to 21 days in an atmosphere of $\mathrm{CO}_{2} 10 \%, \mathrm{H}_{2} 10 \%, \mathrm{~N}_{2} 80 \%$. On these plates colonies with a reduced intensity of pigmentation were recognised. These colonies were sub-cultured, freeze-dried, and grown in the chemostat as described for the parent W50 strain.

\section{Identification of colonial variants}

The identity of the colonial variants was assessed by comparing (a) their ability to make acid from glucose$(0.5 \% \mathrm{w} / \mathrm{v})$-supplemented BM broth, $\mathrm{pH} 7.0$, (b) the presence of pre-formed enzymes in the API ZYM (API, Basingstoke) system, (c) their whole-cell fatty-acid profiles, and (d) their pattern of fermentation products, with those of the parent W50 strain. The API ZYM system was used according to the manufacturer's instructions. Fermentation products were measured in culture supernates by standard gas-liquid chromatographic techniques. Briefly, volatile fatty acids were quantified with a Pye GCV gas chromatograph fitted with a flameionisation detector and a PU 4800 video chromatography control centre for integration; the internal standard was 2-ethyl butyric acid. The column $(2 \mathrm{~m} \times 4 \mathrm{~mm})$ was packed with Chromosorb W (80-100 mesh) coated with carbowax $20 \mathrm{M} 15 \%$ and phosphoric acid $2 \%$ (Chrompack, Middleburg, Holland); the carrier gas was nitrogen (flow rate $20 \mathrm{ml} / \mathrm{min}$ ). The initial oven temperature was $90^{\circ} \mathrm{C}$ and was raised to $118^{\circ} \mathrm{C}$ at $4^{\circ} \mathrm{C} / \mathrm{min}$; the temperatures of the injector and the detector were $250^{\circ} \mathrm{C}$ and $260^{\circ} \mathrm{C}$, respectively. The presence of phenylacetic acid was confirmed by comparison with a standard by mass spectrometry with a Dupont 21-491 instrument operated in the electron impact mode at $70 \mathrm{eV}$.

The fatty-acid profiles of cells grown for 10 days on blood-agar plates were determined as described by Wait and Hudson (1985). Cells were freeze-dried, suspended in $1 \mathrm{ml}$ of toluene: methanol $(1: 1)$, acidified with $25 \mu \mathrm{l}$ of concentrated sulphuric acid and incubated overnight at $60^{\circ} \mathrm{C}$. Samples were cooled, $0.5 \mathrm{ml}$ of saturated sodium chloride solution was added, and the fatty acid methyl esters were extracted with two successive $1 \cdot 5-\mathrm{ml}$ volumes of hexane:chloroform (4:1). The extracts were concentrated to one-third volume under nitrogen, washed with $1 \mathrm{ml}$ of $0.3 \mathrm{M} \mathrm{NaOH}$, and the organic layer was removed and evaporated to dryness. Trimethyl-silyl ethers were prepared by treating the methyl ester with bis(trimethylsilyl)trifluoroacetamide (Fluorchem, Glossop) $20 \%$ in pyridine. Fatty acids were analysed by capillary gas-liquid chromatography in a Carlo-Erba 4130 chromatograph (Carlo-Erba, Milan, Italy), fitted with a 12-m vitreous silica column coated with BP-1 (SGE Ltd, Milton Keynes). Helium was the carrier gas (flow rate $1 \mathrm{ml} / \mathrm{min}$ ), and samples were introduced by splitless injection in isooctane. The initial oven temperature was $80^{\circ} \mathrm{C}$, and was raised to $195^{\circ} \mathrm{C}$ at $40^{\circ} \mathrm{C} / \mathrm{min}$ after a 1 -min delay. Peak identities were established by comparison with standards and by gas-liquid chromatography-mass spectrometry, by use of a Kratos analytical MS80 RFA (Kratos Ltd, Manchester) interfaced to a gas-liquid chromatograph (Carlo-Erba, Milan, Italy). Chromatographic conditions were as described above, and the mass spectrometer was operated at a scan rate of $0.3 \mathrm{~s} /$ decade of mass in electron inpact mode at an ionising energy of $70 \mathrm{eV}$ and $100 \mu \mathrm{A}$ trap current.

\section{Mouse pathogenicity test}

The virulence of the colonial variants was compared with that of the parent strain in a pathogenicity model based on that of van Steenbergen et al. (1982). Bacteria were grown in haemin-excess conditions in the chemostat and injected subcutaneously (s.c.) into mice as described previously (McKee et al., 1986). Viable counts were performed on the inocula to establish the cell dosage. Mice were killed with ether at various stages after infection. Samples of infected tissues taken at necroscopy were fixed in buffered neutral formalin $10 \% \mathrm{v} / \mathrm{v}$ and embedded in paraffin wax by standard procedures. Sections of these blocks were cut at $5-\mu \mathrm{m}$ intervals and stained with haematoxylin and eosin.

\section{Results}

\section{Appearance of colonial variants of B. gingivalis W50}

During the growth of $B$. gingivalis W50 in conditions of haemin excess in a chemostat at $\mathrm{pH}$ $7 \cdot 5$, small volumes of culture were plated on to blood agar for viable count determinations and to check the purity of the culture. After growth for 23 weeks in a chemostat (49-73 bacterial generations), colonies with atypical morphology were observed. These colonies differed from the majority in the intensity of their pigmentation (table I). After anaerobic incubation for 14 days on plates, the colonies of one variant (W50/BE1) were beige, 
Table I. Appearance of colonial variants during growth of B. gingivalis W50 in a chemostat*

\begin{tabular}{|c|c|c|c|c|c|}
\hline \multirow{2}{*}{$\begin{array}{l}\text { Colony } \\
\text { type }\end{array}$} & \multicolumn{2}{|c|}{$\begin{array}{l}\text { Pigmentation on } \\
\text { blood agar after }\end{array}$} & \multicolumn{3}{|c|}{$\begin{array}{l}\text { Approximate percentage } \dagger \text { of colonies } \\
\text { from chemostat culture after }\end{array}$} \\
\hline & 14 days & 21 days & 7 days & 14 days & 21 days \\
\hline Parent, W50 & $\begin{array}{l}\text { black, with } \\
\text { tan centre }\end{array}$ & black & 93 & 88 & 66 \\
\hline W50/BR1 & $\begin{array}{l}\text { brown, with } \\
\text { clear edge }\end{array}$ & dark brown & 1 & .7 & 10 \\
\hline W50/BE1 & beige & $\tan$-dark tan & 6 & 5 & 24 \\
\hline
\end{tabular}

*Cells were grown under haemin excess, $\mathrm{pH} 7 \cdot 5 \pm 0 \cdot 2$, at a constant mean generation time of $6 \cdot 9 \mathrm{~h}$.

† Viable counts were taken from a single chemostat run; similar trends were found with other chemostat experiments.

while those of another were brown (W50/BR1). These colonial variants were only a small percentage of the culture, until after growth for 21 days in the chemostat when the proportions of variant W50/BE1 could reach, on occasions, c. $24 \%$ of the total colony forming units (table I).

\section{Stability of growth of colonial variants on sub-culture}

An example of each of the two variants was subcultured on blood agar and found to breed true. Chemostats were also inoculated with each variant and the cultures were grown in identical conditions to those used originally for the parent W50 strain. A chemostat inoculated with W50/BE1 yielded only beige colony forms even after prolonged incubation; no black or other strongly-pigmenting colonies were ever observed. In contrast, when variant W50/BR1 was grown in the chemostat, other weakly-pigmenting colonies were detected although these were $<10 \%$ of the total colony types during incubation up to 14 days, but increasing to nearly $30 \%$ of the total colony types after growth for 36 days. All three strains were asaccharolytic, being unable to lower the $\mathrm{pH}$ below 7.0 when inoculated into BM broth supplemented with glucose.

\section{Characterisation of the colonial variants}

To determine the relatedness of the variants to the parent strain, comparisons were made of the patterns of fermentation products, the long chain fatty-acid profiles of whole cells, and the presence of key enzymes in a semi-quantitative assay. The fermentation products are listed in table II. The same pattern of acids was produced by all three strains, although low concentrations of iso-caproic and caproic acid were detected only in supernates of strain W50/BR1. All three strains produced similar amounts of phenylacetic acid.

The whole-cell fatty acids of Bacteroides spp. are useful chemotaxonomic markers (Shah and Collins, 1980). Consequently, the profiles of whole cells of the variants were compared with those of W50 and other asaccharolytic Bacteroides spp. which might be confused with $B$. gingivalis (table III). There was a stronger similarity between the fatty-acid profiles of the variants and the parent W50 strain than between these strains and the other Bacteroides spp.

Table II. Acid fermentation products of the parent strain and two colonial variants of $B$. gingivalis W50

\begin{tabular}{|c|c|c|c|}
\hline \multirow{2}{*}{$\begin{array}{l}\text { Fermentation } \\
\text { product }\end{array}$} & \multicolumn{3}{|c|}{$\begin{array}{c}\text { Amount* of product } \\
(\mu \mathrm{mol} / \mathrm{mg} \text { dry wt of cells })\end{array}$} \\
\hline & W50 & W50/BR1 & W50/BEl \\
\hline Acetic acid & $14 \cdot 1(0 \cdot 14)$ & $9 \cdot 7(2 \cdot 3)$ & $13 \cdot 6(1.8)$ \\
\hline Propionic acid & $1.9(0.6)$ & $1.8(0.6)$ & $1 \cdot 7(0.3)$ \\
\hline Iso-butyric acid & $3 \cdot 2(1 \cdot 0)$ & $4 \cdot 3(0 \cdot 7)$ & $3.7(0.9)$ \\
\hline Butyric acid & $16.9(2 \cdot 1)$ & $16 \cdot 6(1 \cdot 8)$ & $11 \cdot 8(1 \cdot 1)$ \\
\hline Iso-valeric acid & $7 \cdot 2(0 \cdot 9)$ & $10 \cdot 2(0 \cdot 6)$ & $5 \cdot 8(0 \cdot 7)$ \\
\hline Valeric acid & $<0 \cdot 1$ & $0.4(0.5)$ & $0.3(0.3)$ \\
\hline Iso-caproic acid & ND & $0.5(0.4)$ & ND \\
\hline Caproic acid & ND & $0.8(0.4)$ & ND \\
\hline Succinic acid & $0 \cdot 2(0 \cdot 1)$ & $0.9(0.2)$ & $0.2(0.02)$ \\
\hline Phenylacetic acid & $1.5(0.6)$ & $1.6(0.7)$ & $1 \cdot 5(0 \cdot 8)$ \\
\hline Hydrocinnamic acid & $<0 \cdot 1$ & $<0.1$ & $<0 \cdot 1$ \\
\hline
\end{tabular}

* Mean of at least three determinations (SD) made on supernates taken on different days from the chemostat. $\mathrm{ND}=$ not detected. 
Table III. Profiles of the major long chain fatty acids of whole cells* of colonial variants of B. gingivalis W50 and other Bacteroides spp.

\begin{tabular}{|c|c|c|c|c|c|c|c|c|}
\hline \multirow[b]{2}{*}{ Species and strain } & \multicolumn{6}{|c|}{ Percentage fatty-acid composition } & \multirow{2}{*}{$\begin{array}{l}\text { Ratio } \\
i-15: \\
a i-15\end{array}$} & \multirow{2}{*}{$\begin{array}{c}\text { Total } \\
\text { hydroxy } \\
\text { fatty aci }\end{array}$} \\
\hline & $i-15$ & $a i-15$ & $3(\mathrm{OH}) 15$ & $16: 0$ & $3(\mathrm{OH}) i-17$ & $18: 2$ & & \\
\hline B. gingivalis W50 & 30 & 7 & 5 & 10 & 30 & 3 & $4 \cdot 3$ & 40 \\
\hline B. gingivalis W50/BR1 & 23 & 6 & 5 & 8 & 39 & 5 & $4 \cdot 1$ & 49 \\
\hline B. gingivalis W50/BE1 & 19 & 4 & 4 & 10 & 44 & 3 & $4 \cdot 8$ & 52 \\
\hline B. endodontalis HG370 & 47 & 3 & 7 & 14 & 12 & 2 & $15 \cdot 7$ & 21 \\
\hline B. asaccharolyticus B536 & 58 & 1 & 5 & 7 & 4 & 3 & $58 \cdot 0$ & 9 \\
\hline B. intermedius $\mathrm{T} 588$ & 12 & 13 & 5 & 5 & 20 & 15 & 0.9 & 27 \\
\hline B. fragilis NCTC 9344 & 13 & 23 & 3 & 7 & 24 & 3 & $0 \cdot 6$ & 34 \\
\hline
\end{tabular}

* Cells were grown on blood-agar plates.

$i-15=13$-methyltetradecanoic acid; ai-15 =12-methyltetradecanoic acid; $3(\mathrm{OH})-15=3$ hydroxy-13-methyl tetradecanoic acid; $16: 0=$ hexadecanoic acid; $3(\mathrm{OH}) i-17=3$-hydroxy-15 methyl hexadecanoic acid $; 18: 2=$ ocatadeca-dienoic acid.

This was particularly marked when the ratios of $i-15: a i-15$ and the total hydroxy-fatty acid contents were compared (table III).

When the enzyme activities of the $\boldsymbol{B}$. gingivalis strains were compared in the API-ZYM standard galleries, all three colony types gave similar profiles - they gave positive results for acid and alkaline phosphatases, $\mathrm{C}_{4}$ and $\mathrm{C}_{8}$ esterases, trypsin, phosphoamidase and $N$-acetyl- $\beta$-glucoaminidase. One consistent difference, however, was that variant W50/BE1 had only weak trypsin activity, whereas both $\mathrm{W} 50$ and $\mathrm{W} 50 / \mathrm{BR} 1$ gave strongly positive reactions.

\section{Pathogenicity of colonial variants of $B$. gingivalis}

$B$. gingivalis W50 is highly virulent when injected s.c. into mice, although this virulence is dosedependent (McKee et al., 1986). Marked differences in disease-producing potential were found when the colonial variants were compared with the parent strain in this simple mouse pathogenicity model (table IV). Both variants were less virulent than W50. At a dose of $1 \times 10^{9}$ viable cells, strains W50/BE1, W50/BR1 and W50 killed 0, 2 and 10 out of groups of 10 mice, respectively. The mortality rate with W50/BR1 increased when higher numbers were injected but W50/BE1 remained avirulent irrespective of the dose.

\section{Pathology of lesions}

In all the mice inoculated with $B$. gingivalis W50 there was spreading inflammation involving the skin of the lower flanks and ventral abdomen. Large areas of skin became hairless, dark brown and scabbed, and on dissection the subcutaneous tissues were distended by a reddish-brown fluid. Histological examination showed extensive exudative and necrotising changes from the epidermis to the abdominal muscle layers, with some localised abscess formation and marked diffuse accumulation of polymorphonuclear leucocytes (PMN) and oedema. Animals given a dose of $\log _{10} 9 \cdot 3$ viable cells of variant W50/BR1 had abdominal skin lesions which were grossly and microscopically similar to those produced by the parent strain. Animals which survived after having been given a smaller dose of W50/BR1 (table IV) had no macroscopic lesions, but histologically there were foci of inflammation

Table IV. Pathogenicity in mice of colonial variants of $B$. gingivalis*

\begin{tabular}{lcc}
\hline Colony type & $\begin{array}{c}\text { Subcutaneous } \\
\text { infective dose } \\
\left(\log _{10} \text { cfu }\right)\end{array}$ & $\begin{array}{c}\text { Number of mouse } \\
\text { deaths/total number of } \\
\text { mice challenged }\end{array}$ \\
\hline Parent W50 & $9 \cdot 3$ & $10 / 10$ \\
& $9 \cdot 0$ & $10 / 10$ \\
& $8 \cdot 7$ & $10 / 10$ \\
Variant W50/BR1 & $7 \cdot 7$ & $0 / 10$ \\
& $9 \cdot 3$ & $8 / 10$ \\
& $9 \cdot 2$ & $2 / 10$ \\
Variant W50/BE1 & $9 \cdot 0$ & $2 / 10$ \\
& $8 \cdot 9$ & $0 / 10$ \\
& $9 \cdot 6$ & $0 / 10$ \\
& $9 \cdot 3$ & $0 / 10$ \\
& $9 \cdot 1$ & $0 / 10$
\end{tabular}

* Bacteria were grown in a chemostat at a dilution rate of $0.1 \mathrm{~h}^{-1}$ (mean growth rate $6.9 \mathrm{~h}$ ) and at constant $\mathrm{pH} 7.5$ in haemin excess conditions. Pathogenicity tests were repeated on different days at various doses with freshly-prepared cells. 
(PMN and histiocytes) in the dermis. Three of the ten mice inoculated with $\log _{10} 9 \cdot 6$ viable cells of variant W50/BE1 had slight localised scab formation on the abdominal skin. Histologically, these animals showed areas of inflammatory changes in the dermis characterised by oedema, PMN infiltration and histiocyte activity, though these changes were not as severe or extensive as with W50 or W50/BR1. The remaining mice and those given a lower infective dose had no macroscopic lesions, and only a few foci of mild dermal inflammation were observed microscopically.

\section{Discussion}

The isolation of spontaneous variants (isogeneic mutants) with reduced virulence has enabled properties to be recognised which contribute to the pathogenicity of several gram-negative bacteria (Birkbeck and Penn, 1986). Generally, these variants have been identified by a fortuitous association of the loss of virulence with either an altered colony appearance or a change in the ability of an organism to grow on certain media. For example, Bordetella pertussis can spontaneously and irreversibly lose virulence factors in a process termed phase variation (Leslie and Gardner, 1931) and the colonial morphology of avirulent forms (corresponding to phases III and IV) are different from those of virulent $B$. pertussis on the same medium (Peppler, 1982; Peppler and Schrumpf, 1984). Similarly, gonococci can produce a number of colonial variants in vitro (Kellogg et al., 1963) and during natural infection (Schwalbe et al., 1985) that differ in the expression of pili and certain outer membrane proteins (Heckels, 1986). These gonococcal variants also differ in their attachment to host surfaces and their ability to undergo antigenic variation may enable cells to evade host defences. Recently, atypical translucent colony forms of Vibrio vulnificus were isolated and all were found to be avirulent and to have lost certain virulence factors (Simpson et al., 1987).

In the present study, atypical colony forms were observed when cultures of $\boldsymbol{B}$. gingivalis were plated on to blood agar. Characteristically, $\boldsymbol{B}$. gingivalis produces black colonies but these colonial variants were recognised by their weak pigmentation. Indeed, variant W50/BE1 exhibited no pigmentation even after incubation for 14 days and colonies became only slightly pigmented after incubation for 21 days. Colonies of this latter variant were originally considered to be most likely those of a contaminant. However, when the properties of W50/BE1 and another variant (W50/BR1) were studied in more detail, both had a phenotype similar to that of $B$. gingivalis W50. In particular, both variants were asaccharolytic and produced a wide range of metabolic end products, with acetic and butyric as major acids, which is characteristic of Bacteroides spp. (Holdeman et al., 1977), and large amounts of phenylacetic acid which distinguishes $B$. gingivalis from other asaccharolytic blackpigmented Bacteroides (Kaczmarek and Coykendall, 1980; Ferguson et al., 1983). Whole-cell fattyacid patterns have been suggested to be of great value in differentiating Bacteroides spp. (Shah and Collins, 1980). Again, the two variants had profiles similar to the parent strain, and all three showed striking differences from other asaccharolytic and related Bacteroides spp. with which they might have been confused. Furthermore, all three strains gave similar reaction patterns in the API ZYM rapid enzyme identification system, and these were consistent with previously published profiles of $B$. gingivalis strains (Slots, 1982b; Laughon et al., 1982), with the exception that variant W50/BE1 had only weakly positive trypsin activity. Nevertheless, the collective evidence is consistent in showing that the variants are closely related to $B$. gingivalis and are, therefore, probably spontaneous isogeneic mutants of strain W50.

A major difference was found when the virulence of the variants was compared in a simple mouse pathogenicity model. In the absence of a suitable animal model of periodontal disease, this system has enabled comparisons to be made of the pathogenic potential of different strains and species of oral Bacteroides (van Steenbergen et al., 1982, 1987; McKee et al., 1986). Previous studies (van Steenbergen et al., 1982; McKee et al., 1986), as well as the work presented here, had shown that $B$. gingivalis strain W50 was highly virulent in mice, causing a fatal infection with widespread exudative and necrotising lesions. Variant W50/BR1 was less virulent than the parent strain and required a higher infective dose to produce similar lesions; variant W50/BE1 was avirulent at all doses tested.

Bacteroides gingivalis produces a range of factors that may enable the organism to evade the host defences and cause tissue damage directly (Slots and Genco, 1984). A comparison of the putative virulence factors produced by the parent strain with those of the variants (and particularly strain W50/BE1) might enable progress to be made in determining the relative importance of individual factors, in a similar manner to that used with variants and mutants of other species such as $B$. pertussis (Robinson et al., 1986) and $N$. gonorrhoeae (Heckels, 1986). It is not known yet whether other 
strains of $B$. gingivalis show a similar tendency to produce variants. The widespread ability of strains to produce variants might indicate a strategy by which $B$. gingivalis could persist during an infection, evading host defences or adapting to an ever-

\section{REFERENCES}

Birkbeck T H, Penn C W (eds) 1986 Antigenic variation in infectious diseases. IRL Press, Oxford.

Ferguson K P, Mayberry W R, Lambe D W 1983 Production of phenylacetic acid by Bacteroides melaninogenicus ssp. intermedius serogroup C-1. Canadian Journal of Microbiology 29: 276-279.

Heckels J E 1986 Gonococcal antigenic variation and pathogenesis. In: Birkbeck T H, Penn C W (eds) Antigenic variation in infectious diseases. IRL Press, Oxford, pp 77-94.

Holdeman L V, Cato E P, Moore W E C 1977 Anaerobe Laboratory Manual, 4th edn. Anaerobe Laboratory, Virginia Polytechnic Institute and State University, Blacksburg, VA, pp 11-44.

Kaczmarek FS, Coykendall A L 1980 Production of phenylacetic acid by strains of Bacteroides asaccharolyticus and Bacteroides gingivalis (sp. nov.). Journal of Clinical Microbiology 12: 288-290.

Kellogg D S, Peacock W L, Deacon W E, Brown L, Pirkle C I 1963 Neisseria gonorrhoeae. I. virulence genetically linked to clonal variation. Journal of Bacteriology 85: 1274-1279.

Laughton B E, Syed S A, Loesche W J 1982 API ZYM system for identification of Bacteroides spp., Capnocytophaga spp., and spirochaetes of oral origin. Journal of Clinical Microbiology 15: 97-102.

Leslie P H, Gardner A D 1931 The phases of Haemophilus pertussis. Journal of Hygiene 31 : 423-434.

McKee A S, McDermid A S, Baskerville A, Dowsett A B, Ellwood D C, Marsh P D 1986 Effect of hemin on the physiology and virulence of Bacteroides gingivalis W50. Infection and Immunity 52: 349-355.

Peppler M S 1982 Isolation and characterisation of isogenic pairs of domed hemolytic and flat nonhemolytic colony types of Bordetella pertussis. Infection and Immunity 35: 840851 .

Peppler M S, Schrumpf M E 1984 Isolation and characterisation of Bordetella pertussis phenotype variants capable of growing on nutrient agar: comparison with phases III and IV. Infection and Immunity 43: 217-223.

Robinson A, Duggleby C J, Gorringe A R, Livey I 1986 changing host environment, as has been suggested for the gonococcus (Heckels, 1986).

We thank Dr R. Owen, Bacterial Metabolism Research Laboratory, for his invaluable assistance with the detection of fermentation products by gas-liquid chromatography.

Antigenic variation in Bordetella pertussis. In : Birkbeck T $\mathrm{H}$, Penn $\mathrm{C} \mathrm{W}$ (eds) Antigenic variation in infectious diseases. IRL Press, Oxford, pp 147-161.

Schwalbe R S, Sparling P F, Cannon J G 1985 Variation of Neisseria gonorrhoeae protein II among isolates from an outbreak caused by a single gonococcal strain. Infection and Immunity 49: 250-252.

Shah H N, Collins M D 1980 Fatty acid and isoprenoid quinone composition in the classification of Bacteroides melaninogenicus and related taxa. Journal of Applied Bacteriology 48: 7587.

Simpson L M, White V K, Zane S F, Oliver J D 1987 Correlation between virulence and colony morphology in Vibrio vulnifcus. Infection and Immunity 55: 269-272.

Slots J $1982 a$ Importance of black-pigmented Bacteroides in human periodontal disease. In: Genco R J, Mergenhagen S E (eds) Host-parasite interactions in periodontal diseases. American Society for Microbiology, Washington DC, pp $27-45$.

Slots J $1982 b$ Enzymatic characterization of some oral and nonoral gram-negative bacteria with the API ZYM system. Journal of Clinical Microbiology 14 : 288-294.

Slots J, Genco R J 1984 Black-pigmented Bacteroides species, Capnocytophaga species, and Actinobacillus actinomycetemcomitans in human periodontal disease: virulence factors in colonization, survival and tissue destruction. Journal of Dental Research 63: 412-421.

van Steenbergen T J M, Kastelein P, Touw J J A, de Graaff J 1982 Virulence of black-pigmented Bacteroides strains from periodontal pockets and other sites in experimentally induced skin lesions in mice. Journal of Periodontal Research 17: 41-49.

van Steenbergen T J M, Delemarre F G A, Namavar F, de Graaff J 1987 Differences in virulence within the species Bacteroides gingivalis. Antonie van Leeuwenhoek 53: 233244.

Wait R, Hudson M J 1985 The use of picolinyl esters for the characterisation of microbial lipids: application to the unsaturated and cyclopropane fatty acids of Campylobacter species. Letters in Applied Microbiology 1 : 95-99. 